\title{
Pengembangan Potensi Wisata di Pantai Sempaning Desa Adat Jimbaran
}

\author{
https://doi.org/10.32509/am.v4i1.1351
}

\author{
Ade Pralinda ${ }^{1}$ dan Putri Ekaresty Haes ${ }^{2}$ \\ ${ }^{1,2}$ Universitas Pendidikan Nasional \\ Jl. Bedugul No.39, Denpasar, Bali - Indonesia \\ Email Korepondensi: adepraalinda@gmail.com
}

\begin{abstract}
This community service was carried out in Jimbaran Traditional Village. This service was motivated by the less than optimal utilization and management of Sempaning Beach. Where this service aims to find ways to develop tourism potential in Sempaning Beach, Jimbaran Traditional Village. The method used in this service is the SWOT analysis method (Strength, Weakness, Opportunity, and Threat). The steps used from this service go through several stages, namely the preparation stage and the implementation stage. The preparatory stage is carried out to prepare everything needed, such as determining a theme and conducting a literature study and the possibilities that will occur in the field. The implementation stage consists of observation, planning, creating an Instagram account, uploading photos / videos on Instagram, documentation, socialization and filling out a questionnaire. The result of this dedication is the creation of an Instagram social media account as a branding medium for Sempaning Jimbaran Beach to be better known by the wider community and tourists. The second is providing online socialization through the whatsapp group media to ST members. Bakti Asih br. Teba Desa Adat Jimbaran regarding the concept of CBT-based tourism (Community Based Tourism) so that it can be applied on Sempaning Beach. Where the concept of CBT (Community Based Tourism) is very useful if realized on Sempaning Beach because it can improve the economic sector of the people of the Traditional Village of Jimbaran.
\end{abstract}

Keywords: Potential tourism, Sempaning Beach, Instagram, the concept of CBT (Community Based Tourism)

\begin{abstract}
Abstrak - Pengabdian masyarakat ini dilaksanakan di Desa Adat Jimbaran.Pengabdian ini dilatarbelakangi oleh pemanfaatan dan pengelolaan Pantai Sempaning yang kurang maksimal. Dimana pengabdian ini bertujuan untuk mengetahui cara-cara mengembangkan potensi wisata yang ada di Pantai Sempaning Desa Adat Jimbaran. Metode yang digunakan dalam pengabdian ini adalah metode analisis SWOT (Strenght, Weakness, Opportunity, and Threat). Langkah-langkah yang digunakan dari pengabdian ini melalui beberapa tahapan yaitu tahap persiapan dan tahap pelaksanaan. Tahap persiapan dilakukan untuk mempersiapkan segala sesuatu yang diperlukan seperti menentukan tema dan melakukan studi pustaka dan kemungkinan yang akan terjadi dilapangan. Tahap pelaksanaan terdiri dari observasi, perencanaan, pembuatan akun Instagram, pengunggahan foto/video di Instagram, dokumentasi, sosialisasi dan pengisian kuisioner. Hasil dari pengabdian ini adalah berupa pembuatan akun media sosial Instagram sebagai media branding bagi Pantai Sempaning Jimbaran agar lebih dikenal oleh masyarakat luas maupun para wisatawan. Yang kedua adalah pemberian sosialisasi secara daring melalui media whatsapp grup kepada anggota ST. Bakti Asih br. Teba Desa Adat Jimbaran mengenai konsep wisata berbasis CBT (Community Based Tourism) agar dapat diterapkan di Pantai Sempaning. Dimana konsep CBT (Community Based Tourism) ini sangat bermanfaat jika direalisasikan di Pantai Sempaning karena dapat meningkatkan sector perekonomian masyarakat Desa Adat Jimbaran..
\end{abstract}

Kata kunci: Potensi wisata, Pantai Sempaning, Instagram, Konsep CBT (Community Based Tourism)

\section{PENDAHULUAN}

Indonesia merupakan salah satu Negara yang memiliki banyak pulau di dunia. Lebih dari 17.000 pulau tersebar di seluruh penjuru Indonesia. Sehingga Indonesia memiliki beraneka ragam suku, agama, budaya, adat istiadat, ras, bahasa, serta potensi wilayah yang berbeda-beda. Indonesia merupakan salah satu Negara yang penghasilan pariwisatanya sangat menjanjikan. Terbukti bahwa sektor pariwisata merupakan salah satu sektor penunjang devisa Negara tertinggi. Letak geografis Indonesia yang luas menambah nilai lebih bagi berkembangnya 
sektor pariwisata karena setiap daerah memiki kondisi geografis yang berbeda-beda sehingga setiap wilayah memiliki potensi yang beragam. Salah satu daerah yang memiliki potensi alam yang berlimpah adalah daerah pesisir pantai. Pengembangan potensi wisata daerah pesisir pantai saat ini difokuskan pada pemandangan, ekosistem dan karakteristik pantai yang berbedabeda di setiap daerahnya.

Bali adalah salah satu pulau yang memiliki banyak daerah pesisir pantai. Salah satunya adalah kabupaten Badung. Kabupaten ini merupakan kabupaten yang hampir semua pantainya merupakan pantai pasir putih. Terutama di daerah Badung bagian selatan tepatnya di desa Adat Jimbaran. Desa Adat Jimbaran merupakan salah satu desa yang berada di Kabupaten Badung bagian selatan dimana Desa Adat Jimbaran memiliki luas wilayah sebesar $20,50 \mathrm{~km}^{2}$. Desa Adat Jimbaran memiliki 14 Banjar dimana terdiri dari 12 banjar adat dan 2 banjar dinas. Gambaran topografi daerah Desa Adat Jimbaran adalah sebagian berupa daratan sebagian lagi berupa perbukitan barrier sedang (data profil Kabupaten Badung).

Desa Adat Jimbaran sangat terkenal dengan keindahan pemandangan pantai pasir putih beserta pemandangan batu karang dan tebing yang dimilikinya. Tidak heran jika di Desa Adat Jimbaran terdapat banyak restaurant dan hotel-hotel dari bintang 3 hingga dinamond yang berjejer di pinggir pantai. Hal ini menyebabkan masyarakat Desa Adat Jimbaran dalam memenuhi kebutuhan hidupnya kebanyakan bergantung pada sektor pariwisata.

Seperti Pantai Jimbaran, Pantai Tegal Wangi, Pantai Mimpi dan Pantai Muaya. Semua Pantai tersebut sudah banyak diketahui oleh wisatawan baik lokal maupun internasional karena keindahan wisata pantai pasir putih dan batu karangnya. Letak pantai yang dekat dengan Bandara Internasional I Gusti Ngurah Rai menyebabkan pantai-pantai tersebut tidak pernah sepi pengunjung.

Namun masih banyak daerah pantai di Desa Adat Jimbaran yang belum dikenal oleh wisatawan baik wisatawan lokal maupun internasional, sehingga pantai tersebut tidak dimanfaatkan potensinya dengan maksimal salah satu contoh adalah Pantai Sempaning. Pantai ini terletak di daerah bukit jimbaran tepatnya di selatan Pantai Muaya yang dibatasi oleh tebing batu kapur. Kondisi Pantai Sempaning memiliki potensi wisata yang menjanjikan. Dimana pemandangan pantai pasir putih ini tidak kalah indah dari pantai-pantai yang sudah terkenal di Jimbaran.

Saat ini penggunaan media sosial dalam membranding suatu objek sangatlah diminati oleh masyarakat. Media sosial adalah sebuah istilah yang menggambarkan bermacam-macam teknologi yang digunakan untuk mengikat orang-orang ke dalam suatu kolaborasi, saling bertukar informasi, dan berinteraksi melalui isi pesan yang berbasis web. Dikarenakan internet selalu mengalami perkembangan, maka berbagai macam teknologi dan fitur yang tersedia bagi pengguna pun selalu mengalami berbagai perubahan. Hal ini menjadikan media sosial lebih hypernym dibandingkan sebuah referensi khusus terhadap berbagai penggunaan atau rancangan (Michael Cross,2013). Di Era 4.0 banyak sekali media sosial yang digunakan di Indonesia antara lain: Youtobe, Instagram, Line, Twitter, Facebook dan Whatsapp. Menurut hootsite Indonesia digital report (2020) jumlah pengguna Instagram di Indonesia merupakan jumlah terbesar nomor 3 yang paling aktif yaitu sebesar $79 \%$ dari jumlah populasi. Menurut data yang dirilis oleh Nappoleon Cat pada periode Januari-Mei 2020 jumlah pengguna Instagram di Indonesia sebanyak 69,2 juta pengguna. Dimana para pengguna Instagram di Indonesia didominasi oleh golongan usia produktif yaitu 18-34 tahun. Tidak heran jika Instagram merupakan salah satu media sosial yang digunakan untuk melakukan promosi digital. Beberapa alasan mengapa membuat Instagram merupakan solusi untuk membranding potensi wisata dari Pantai Sempaning adalah:

1. Fitur Instagram, yakni InstaStory.

InstaStory dapat disimpan selama 24 jam. Dimana fitur ini bisa membantu untuk berinteraksi dengan calon wisatawan secara langsung. Karena biasanya, wisatawan 
lebih suka mencari tempat berlibur melalui rekomendasi-rekomendasi yang ada di Instagram. Sebagai pengelola akun Instagram @ sempaningbeach akan selalu merespon komentar atau pesan dan menjalin hubungan baik dengan calon wisatawan. Adanya fitur InstaStory ini juga dapat dimanfaatkan sebagai alat untuk bekerja sama dengan brand lain atau influencer dengan cara menyebut @ sempaningbeach di instastory si influencer maupun brand lain.

2. Keindahan pemandangan Pantai Sempaning dapat dipromosikan dengan menggunakan fitur feeds jika ingin mengunggah foto dan fitur IGTV apabila ingin mengunggah video. Apabila kita ingin lebih dikenal oleh kalangan masyarakat sebaiknya menggandeng influencer yang sedang berlibur ke Bali untuk mengunjungi Pantai Sempaning dan memintanya untuk memposting gambar di feeds mengenai keindahan Pantai Sempaning sehingga otomatis masyarakat luas akan mengetahui keberadaan Pantai Sempaning ini. Masyarakat yang tertarik pasti akan mencari tahu lokasi dari Pantai tersebut dengan mengklik lokasi yang tertera ataupun mengklik akun@sempaningbeach yang telah di tandai oleh influencer tersebut dan kemungkinan akun@sempaningbeach akan bertambah followersnya. Jika akun @sempaningbeach semakin banyak memiliki followers maka semakin mudah untuk membranding Pantai tersebut. Sehingga Pantai Sempaning akan banyak dikenal oleh masyarakat.

3. Mengunakan fitur hastag

Fitur hastag tidak hanya dimiliki oleh twitter dan youtube namun hastag juga bisa digunakan di aplikasi Instagram. Fitur hastag memiliki pengaruh besar terhadap kepopuleran akun Instagram yang kita miliki. Hashtag juga dapat dipakai untuk menambah jumlah followers di Instagram. Apabila kalian menggunakan hashtag yang sesuai di foto kalian, maka kalian bisa dengan mudah untuk menambah jumlah followers akun kita sebab mereka bisa dengan mudah menemukan akun instagram kita hanya dengan mencari atau mengklik hastag yang kita buat. Misalnya kita menyepakati untuk menggunakan \#sempaningbeach untuk membranding Pantai Sempaning maka setiap kita mengunggah foto maupun instastory harus menggunakan \#sempaningbeach sebagai pelengkap captions.

Mengingat Pantai Sempaning memiliki potensi dan peluang yang besar dalam sektor pariwisata dan sebagai salah satu daya tarik wisata maka perlu ditindaklanjuti dengan pengembangan potensi wisata yang sesuai dengan keadaan di kawasan Pantai Sempaning agar menjadi kawasan wisata unggulan. Dalam pengembangan pariwisata Pantai Sempaning diperlukan suatu upaya untuk melestarikan dan mengembangkan potensi wisata yang dimiliki Pantai Sempaning.

Community Based Tourism muncul sebagai sebuah alternatif dari arus utama (mainstream) pengembangan pariwisata. Nicole Hausler (2005) dalam Tourism Forum International mendefinisikan CBT (Community Based Tourism) sebagai bentuk pariwisata yang memberikan kesempatan kepada masyarakat lokal untuk mengontrol dan terlibat dalam manajemen dan pengembangan pariwisata. Menurut (Arifin, 2017) keterlibatan masyarakat sekitar dalam pengelolaan daya tarik wisata merupakan bentuk penerapan dari konsep CBT (Community Based Tourism). CBT (Community Based Tourism) memiliki arti sebagai suatu konsep yang mengutamakan pemberdayaan masyarakat sekitar dalam mengembangkan suatu destinasi wisata. Ada beberapa prinsip-prinsip pokok dalam strategi perencanaan pembangunan kepariwisataan berbasis Community Based Tourism, antara lain: (1) Perwakilan masyarakat ikut serta dalam pengambilan keputusan mengenai perancangan, pemberdayaan suatu tempat yang akan dijadikan destinasi wisata; (2) Masyarakat lokal memiliki jaminan untuk menerima manfaat dari kegiatan kepariwisataan tersebut; (3) Pemberian edukasi tentang pariwisata dan bagaimana cara mengembangkan pariwisata berbasis CBT (Community Based Tourism) bagi 
masyarakat lokal (Sunaryo, 2013: 140). Penerapan konsep CBT (Community Based Tourism) dalam menjalankan wisata dapat membantu Negara agar tidak terjadinya kebocoran devisa Negara. Konsep CBT (Community Based Tourism) sangat menguntungkan bagi daerah yang menerapkannya karena hasil pendapatannya akan dirasakan sepenuhnya oleh pemerintah dan masyarakat sekitar.

Letak Pantai Sempaning yang strategis dan tidak terlalu jauh dari permukiman warga memungkinkan jika penerapan keberlanjutan pariwisata kedepannya menggunakan konsep CBT (Community Based Tourism). Saat ini Pantai Sempaning belum menerapkan konsep CBT (Community Based Tourism) karena keterbatasan sumber daya manusia yang berkualitas dalam mengetahui bagaimana penerapan konsep CBT (Community Based Tourism) yang benar. Diharapkan dengan mengembangkan konsep CBT (Community Based Tourism) yang baik dan benar dalam mengelola Pantai Sempaning dapat memberikan dampak yang baik bagi masyarakat sekitar dan Desa Adat Jimbaran pada umumnya. Perlunya perhatian khusus dari pemerintah jika ingin mengembangkan kawasan pariwisata berbasis CBT (Community Based Tourism) agar terciptanya kawasan pariwisata yang baik dan tentunya dapat menggerakkan perekonomian masyarakat kedepannya.

Pembuatan media sosial dan pengembangan potensi wisata berkelanjutan berbasis CBT (Community Based Tourism) merupakan salah satu cara untuk mengembangkan potensi wisata yang terdapat di Pantai Sempaning. Selain itu melalui pengembangan berkelanjutan menggunakan konsep CBT (Community Based Tourism) diharapkan sektor industri pariwista dapat menjadi instrumen pembangunan yang lebih menekankan pada kesejahteraan dan pemberdayaan masyarakat lokal sekitar tempat wisata tersebut.

Berdasarkan uraian diatas, maka saya tertarik untuk melakukan pengabdian masyarakat di Desa Adat Jimbaran mengenai pemberian masukan, saran dan ide untuk strategi pengembangan potensi wisata di Pantai Sempaning Desa Adat Jimbaran.

\section{METODE PELAKSANAAN}

Kegiatan pengabdian ini dilakukan di Desa Adat Jimbaran, Kecamatan Kuta Selatan, Kabupaten Badung, Provinsi Bali. Adapun ruang lingkup pengabdian yang digunakan yaitu lebih memfokuskan pada strategi pengembangan potensi wisata di Pantai Sempaning Jimbaran. Dimana pengabdian ini akan memberikan gagasan dan ide mengenai hal-hal yang harus dilakukan dalam mengembangkan potensi wisata di Pantai Sempaning sehingga Pantai ini dapat lebih terorganisir dan lebih dikenal oleh wisatawan baik domestik maupun internasional.

Pada tahap pelaksanaan, kegiatan pengabdian ini dilakukan dengan 6 tahapan antara lain: observasi, perencanaan, pembuatan akun media sosial Instagram, dokumentasi, sosialisasi dan pengisian kuisioner melalui google form. Solusi yang ditawarkan adalah memberikan saran untuk membranding Pantai Sempaning di Media sosial Instagram dan mengaplikasikan pariwisata berkelanjutan berbasis CBT (Community Based Tourism) dalam mengembangkan potensi wisata di Pantai Sempaning.

1. Tahap Persiapan

Tahap persiapan dilakukan 2 minggu sebelum kegiatan. Adapun hal-hal yang dilakukan pada saat tahap persiapan antara lain:

1. Menentukan lokasi kegiatan

2. Menentukan tema yang akan diangkat

3. Mencari refrensi-refrensi di jurnal yang berkaitan dengan tema

4. Membuat catatan mengenai hal-hal yang akan dilakukan untuk merealisasikan tema yang akan diangkat tersebut

5. Meminta ijin ke pihak yang berkaitan seperti kepada salah satu anggota LPM (Lembaga Pemberdayaan Masyarakat) Desa Adat Jimbaran agar pelaksanaan kegiatan ini dapat dilaksanakan dengan baik dan agar tidak terjadi disinformasi dalam pelaksanaan kegiatan ini 
2. Tahap Pelaksanaan

Tahap pelaksanaan kegiatan ini dilakukan mulai dari tanggal 1 Februari hingga 17 Maret 2021. Adapun kegiatan yang akan dilakukan antara lain:

1. Observasi

Melakukan pengamatan terhadap suatu objek yang akan dijadikan bahan dalam kegiatan pengadian ini. Dalam hal ini objek yang dimaksud adalah suatu permasalahan yang sedang di hadapi di Desa Adat jimbaran. Dalam observasi ini ditemukan suatu permasalahan pengelolaan salah satu pantai yang ada di Desa Adat Jimbaran. Pantai terseebut memiliki potensi wisata yang sangat baik namun belum dikelola dan dimanfaatkan dengan baik oleh pemerintah setempat. Pantai tersebut adalah Pantai Sempaning yang terletak di kawasan perbukitan Jimbaran sekitar kawasan hotel and resort Ayana Jimbaran.

2. Perencanaan

Pada tahapan ini dilakukan sebuah perencanaan mengenai solusi yang akan di berikan terhadap permasalahan yang ada yaitu dengan cara membuat akun Instagram untuk Pantai Sempaning dan memberikan masukan untuk mengelola potensi wisata Pantai Sempaning dengan konsep CBT (Community Based Tourism)

3. Pembuatan Akun Instagram

Adapun langkah-langkah yang harus dilakukan untuk membuat akun Instagram @ sempaningbeach antara lain:

1. Download aplikasi Instagram di android store/apple store

2. Buka aplikasi Instagram

3. Pilih create akun

4. Tulis nama pengguna akun. Biasanya diminta nama email yang akan didaftarkan

5. Jika sudah menuliskan email maka akan terdapat rekomendasi username dari pihak Instagram agar tidak ada kesamaan nama pengguna satu dengan pengguna lainnya. Disini nama pengguna akun yang dipilih adalah @ sempaningbeach

6. Tulis kata sandi. Diharapkan kata sandi tidak sama dengan nama pengguna agar tidak mudah untuk di retas.

7. Tulis ulang kata sandi yang sama untuk mengkonfirmasi kata sandi

8. Pilih create akun

9. Setelah pembuatan akun selesai kemudian pilih edit profile

10. Masukkan profile foto, name, website dan bio sesuai dengan yang diperlukan untuk kelengkapan informasi mengenai akun tersebut.

4. Dokumentasi

Dokumentasi merupakan suatu metode yang digunakan untuk mengumpulkan data berupa gambar maupun video mengenai objek yang ditentukan. Pengabdian ini mengambil gambar berupa keindahan pemandangan dan batu karang di Pantai Sempaning dan sesekali mendapatkan gambar nelayan yang sedang mencari ikan menggunakan perahu. Pengambilan gambar sudah disetujui oleh nelayan tersebut. Pengambilan gambar tersebut dilakukan di sore hari menggunakan media handphone. Beberapa hasil dari dokumentasi akan di unggah di media sosial Instagram @ pantaisempaning.

5. Pengunggahan foto ke Instagram

Adapun langkah-langkah yang dilakukan dalam proses pengunggahan foto ke Instagram antara lain:

1. Buka aplikasi Instagram di handphone/ PC

2. Setelah itu klik tanda (+) untuk menambahkan foto atau video

3. Pilih foto atau video yang akan diunggah

4. Tambahkan deskrispi captions pada foto atau video dan juga tambahkan \#sempaningbeach untuk mempermudah pencarian Pantai Sempaning

5. Klik lanjutkan

6. Tunggu beberapa detik, foto atau video akan terunggah 
7. Lakukan langkah-langkah yang sama untuk mengunggah foto atau video berikutnya

\section{Sosialisasi}

Pada tahapan sosialisasi ini dilakukan secara daring mengingat pada tahun ini masih berlangsungnya kebijakan pemerintah mengenai menjaga jarak dan menghindari kerumunan. Sehingga sosialisasi dilakukan melalui media grup Whatsapp. Tema yang diangkat dalam sosialisasi ini adalah Penerapan Konsep CBT (Community Based Tourism) dalam Mengembangkan Potensi Wisata di Pantai Sempaning Desa Adat Jimbaran. Sosialisasi ini diberikan kepada anggota aktif ST. Bakthi Asih Banjar Teba Jimbaran yang berjumlah 20 orang. Dan sosialisasi ini dilakukan pada tanggal 23 Februari 2021.

\section{Pemberian Kuisioner}

Pemberian kuisioner dilakukan setelah kegiatan sosialisasi dan tanya jawab dilaksanakan. Responden diwajibkan untuk menjawab pertanyaan-pertanyaan yang berkaitan dengan tema sosialisasi yang telah diberikan. Pemberian Kuisioner dilakukan secara online yaitu melalui google form. Adapun list pertanyaan yang perlu dijawab oleh responden antara lain:

a. Apakah sebelum sosialisasi secara daring anda mengetahui apa itu konsep CBT (Community Based Tourism) pada pengembangan wisata?

b. Apakah sosialisasi secara daring mengenai konsep CBT (Community Based Tourism) dirasa cukup efektif?

c. Apakah setelah sosialisasi secara daring anda bisa memahami konsep CBT (Community Based Tourism) secara umum?

d. Apakah menurut anda Konsep CBT (Community Based Tourism) ini dapat dikembangkan di Pantai Sempaning Jimbaran?

\section{HASIL DAN PEMBAHASAN}

\subsection{Pengembangan potensi wisata di Pantai Sempaning Jimbaran dengan Media Sosial Instagram}

Dari solusi yang sudah rencanakan, kegiatan ini berhasil merealisasikan sebuah progam pembuatan akun Instagram untuk mendukung branding Pantai sempaning dengan konsep digital yaitu menggunakan akun Instagram. Hasil dari progam kerja utama pengabdi dalam kuliah kerja nyata ini adalah sudah memberikan solusi terhadap permasalahan mengenai kurangnya pengetahuan masyarakat luas terhadap adanya surga yang tersembunyi di Pantai Sempaning. Pembuatan akun media sosial seperti Instagram merupakan solusi yang terbaik untuk membranding keindahan Pantai Sempaning. Dengan memposting foto beserta video di akun Instagram tersebut dan menambahkan captions \#sempaningbeach dapat menambah pengetahuan masyarakat mengenai Pantai Sempaning sehingga Pantai Sempaning bisa popular seperti pantai-pantai lainnya yang ada di Bali khususnya yang ada di Desa Adat Jimbaran. Berikut adalah gambar tampilan awal profile akun Instagram @ sempaningbeach. 


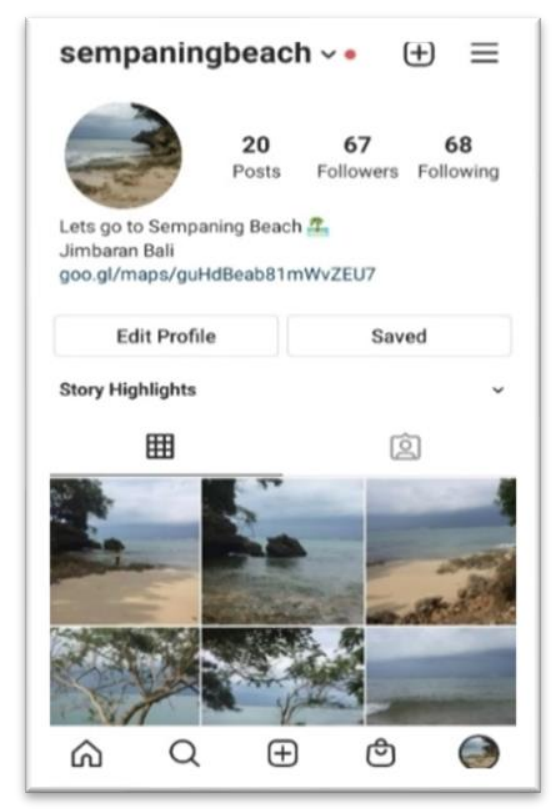

Gambar 1. profil Instagram Pantai Sempaning

Akun Instagram sempaning beach mendapat respon positif dari masyarakat, terbukti hanya dengan 20 post sudah banyak orang yang mulai mengikuti akun Instagram ini ataupun mengunjungi akun Instagram ini. Berikut tampilan tools reach dari akun Instagram @ sempaningbeach. Tampilan tools reach merupakan tools yang membuktikan adanya interkasi bahwa akun ini sudah mendapat respon positif

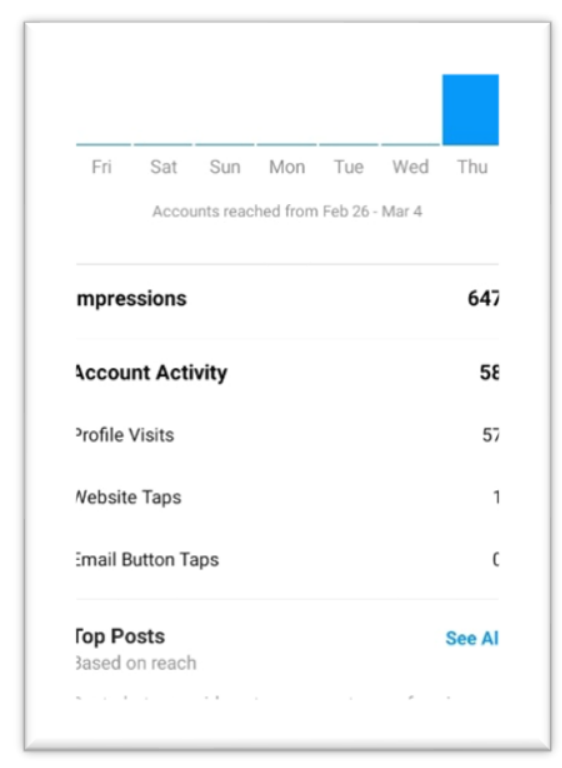

Gambar 2 tampilan reach akun @ sempaningbeach

Dapat dilihat dari gambar 2 bahwa akun Instagram @sempaningbeach mendapat tanggapan positif dari masyarakat. Terbukti dari adanya impressions sebanyak 647 kali, account activity sebanyak 58 akun, profile visits sebanyak 57 akun dan website tab sebanyak 1 kali. Dari total jumlah suka juga dapat dikatakan sukses karena rata-rata postingan yang di unggah di akun Instagram @ sempaningbeach mendapatkan suka sebanyak 32-35 suka hanya dalam 15 jam. 


\subsection{Sosialisasi pengembangan potensi wisata di Pantai Sempaning Jimbaran berbasis CBT (Community Based Tourism)}

Untuk penerapan konsep CBT (Community Based Tourism) pada pengelolaan dan pemanfaatan keberlanjutan pariwisata di Pantai Sempaning Jimbaran sudah dilakukannya kegiatan sosialisasi mengenai gambaran umum tentang konsep CBT (Community Based Tourism) melalui media Whatsapp grup. Media edukasi yang digunakan dalam penyampaian materi adalah dengan menggunakan media power point (ppt). Sasaran dari sosialisasi ini adalah anggota aktif ST. Bakti Asih Banjar Teba Jimbaran yang berjumlah 20 orang. Dalam kegiatan sosialisasi ini dilakukan dengan beberapa segmen yaitu: Segmen pertama pemberian materi dengan cara membagikan materi di media whatsapp grup, sesi Tanya jawab, di sesi ini diberikan waktu bagi anggota aktif ST. Bakti Asih br. Teba Jimbaran, sesi pemberian kesimpulan, dan yang terakhir sesi pemberian kuisioner online berupa google form kepada anggota aktif ST. Bakti Asih br. Teba Jimbaran.

Dalam sesi Tanya jawab terdapat sebuah pertanyaan dari salah satu anggota aktif ST. Bakti Asih yaitu: "Apakah pengembangan program CBT (Community Based Tourism) cocok diterapkan di kawasan Pantai Sempaning Jimbaran ini?". Dan pengabdi menjawab bahwa konsep CBT (Community Based Tourism) sangat cocok diterapkan di Pantai Sempaning Jimbaran dikarenakan pantai ini berlokasi di dekat bandara Internasional I Gusti Ngurah Rai sehingga sangat menjanjikan untuk menjalankan suatu usaha di di pantai tersebut dan juga letaaknya yang berdekatan dengan perumahan dapat memudahkan masyarakat lokal untuk berpartisipasi langsung dalam pengembangan potensi wisata yang ada. Berikut adalah bukti dari kegiatan sosialisasi melalui media whatsapp grup ST. Bakti Asih br. Teba Jimbaran.

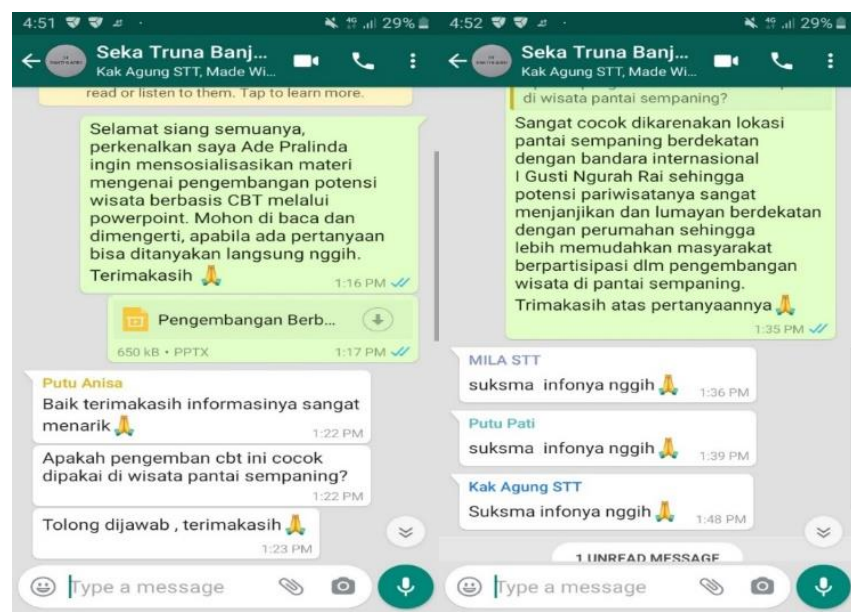

Gambar 3 sosialisasi melalui media whatsapp grup

Berikut adalah hasil presentase responden yang menjawab semua pertanyaan dalam bentuk diagram lingkaran mengenai sosialisasi konsep CBT (Community Based Tourism) yang dilakukan menggunakan aplikasi google form

Apakah sebelum sosialisasi secara daring anda mengetahui apa itu konsep CBT (Community

Based Tourism) pada pengembangan wisata?

20 tanggapan
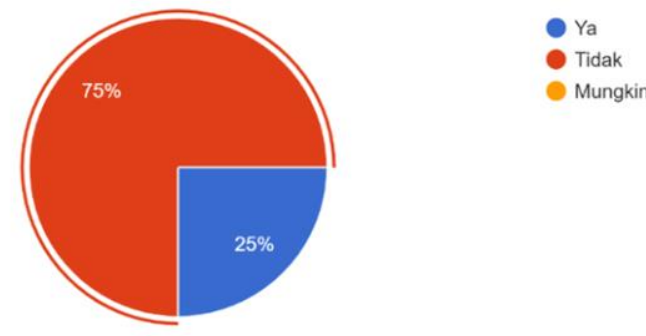
Apakah setelah sosialisasi secara daring anda bisa memahami konsep CBT secara umum?

20 tanggapan
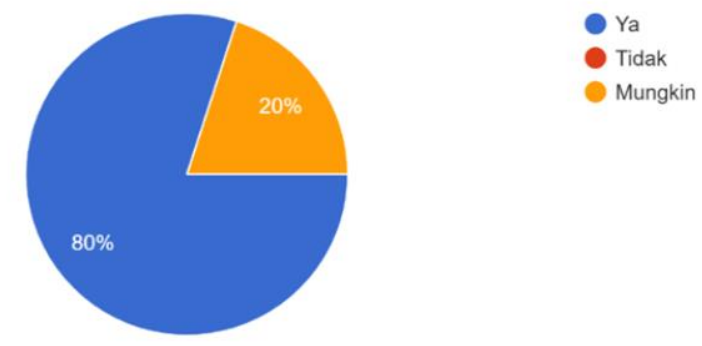

Apakah sosialisasi secara daring mengenai konsep CBT dirasa cukup efektif? 20 tanggapan
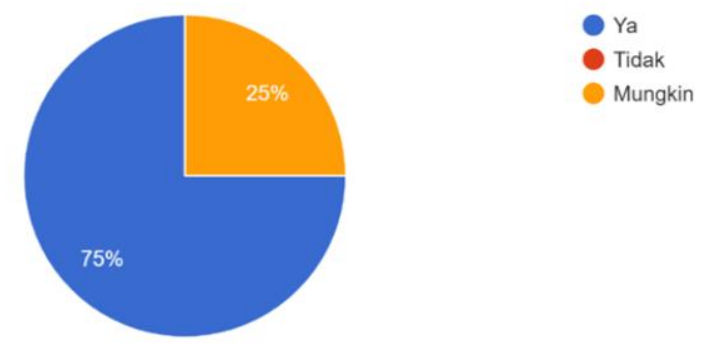

Apakah menurut anda Konsep CBT ini dapat dikembangkan di Pantai Sempaning?

20 tanggapan
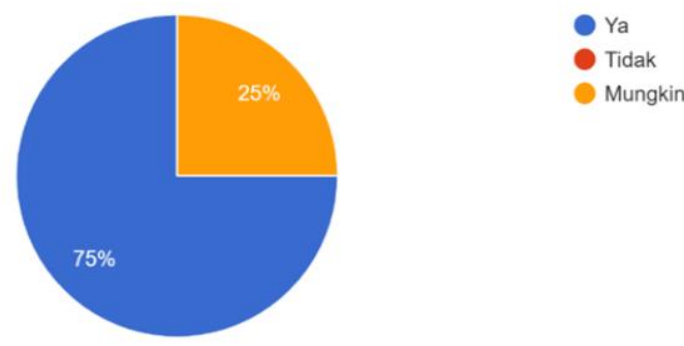

Berikut merupakan ulasan dari diagram lingkaran diatas:

1. Sebelum dilakukannya sosialisasi secara daring, presentase anggota ST. Bakti Asih Br. Teba yang tidak mengetahui konsep CBT (Community Based Tourism) adalah sebesar 75\% sedangkan sisanya menjawab mungkin (sedikit mengetahui).

2. Pelaksanaan sosialisasi secara daring di masa pandemi ini dirasa cukup efektif. Terbukti dari $75 \%$ responden mengatakan Iya dan sisanya menjawab mungkin

3. Setelah pelaksanaan sosialisasi secara daring, $80 \%$ responden dapat memahami gambangan umum mengenai konsep CBT (Community Based Tourism) dan sisanya menjawab mungkin.

4. Sebanyak $75 \%$ responden mengatakan bahwa konsep CBT (Community Based Tourism) ini dapat diterapkan di Pantai Sempaning dan sisanya menjawab mungkin. 
Program pengabdian masyarakat menngajukan rencana tindak lanjut antara lain:

1. Mengharapkan kedepannya potensi Pantai Sempaning dapat dikelola dengan pengelolaan berbasis CBT (Community Based Tourism)

2. Pembentukan struktur keanggotaan POKDARWIS (Kelompok Sadar Wisata)

3. Pemberian pelatihan dan edukasi kepada anggota POKDARWIS (Kelompok Sadar Wisata) dan masyarakat sekitar secara berkala

4. Kekonsistenan penggunaan media sosial Instagram untuk melakukan promosi digital Pantai Sempaning Jimbaran

5. Membentuk kerjasama dengan pihak luar seperti influencer untuk membantu mempromosikan Pantai Sempaning ini

6. Pembuatan akun media sosial lainnya seperti youtube, tiktok, facebook dan membuat halaman website untuk membranding Pantai Sempaning

\section{SIMPULAN}

Adapun kesimpulan yang dapat ditarik dari laporan pengabdian ini antara lain:, Pertama, Dari hasil yang dapatkan dalam pengabdian ini dapat disimpulkan bahwa pemanfaatan instagram disini berarti menggunakan atau memanfaatkan instagram sebagai media sosial yang membranding Pantai Sempaning dalam menyampaikan informasi mengenai potensi wisata yang dimilikinya kepada para wisatawan. Diharapkan dengan adanya Instagram @ pantaisempaning dapat memberikan hasil berupa pengetahuan yang berguna bagi publik yang membaca bahkan melihatnya, yang dalam hal ini adalah para wisatawan yang datang ke Bali. Sehingga wisatawan menjadi tahu tentang keberadaan Pantai Sempaning beserta keindahannya melalui instagram. Dengan instagram seseorang dapat mengetahui bagaimana keadaan realita di Pantai tersebut dan dapat menjadikan Pantai Sempaning sebagai salah satu objek wisata yang dimasukkan ke dalam list ketika berwisata ke Bali. Kedua, Pengelolaan Pantai Sempaning secara berkelanjutan juga harus diperhatikan agar keberadaan Pantai Sempaning ini dapat membawa dampak positif yang bagi masyarakat sekitar Pantai maupun Desa Adat Jimbaran itu sendiri. Pemberian sosialisi mengenai pemahaman gambaran umum konsep CBT (Community Based Tourism) dapat menambah wawasan kepada anggota akif ST. Bakti Asih. Konsep CBT (Community Based Tourism) merupakan suatu konsep pariwisata yang mengutamakan pemberdayaan masyarakat lokal. Sehingga konsep CBT (Community Based Tourism) lebih sering disebut konsep yang berasal dari rakyat dan untuk rakyat itu sendiri. Konsep CBT (Community Based Tourism) merupakan salah satu konsep yang disetujui oleh anggota ST. Bakti Asih br Teba Jimbaran untuk diimplementasikan dalam pengelolaan berkelanjutan Pantai Sempaning ini. Hal ini dikarenakan konsep ini dapat membantu perekonomian masyarakat sekitar dan juga letak Pantai ini tidak terlalu jauh dari permukiman masyarakat sekitar. Diharapkan Konsep CBT (Community Based Tourism) ini dapat memjadikan Pantai Sempaning sebagai salah satu destinasi yang wajib dikunjungi ketika wisatawan sedang berlibur di Pulau Dewata khususnya di Kabupaten Badung bagian selatan.

\section{Daftar Pustaka}

Diantha, Made Pasek, dkk. 2017. Kajian Yuridis Tentang Perubahan Status Kelurahan Menjadi Desa Di Kabupaten Badung. Universitas Udayana. https://simdos.unud.ac.id/uploads/file_penelitian_1_dir/0b05c9cd69bea1d25a4bc74e64d9683 9.pdf. Diakses Pada 20 Februari 2021.

Franzia, Elda. Personal Branding Melalui Media Sosial. Seminar Nasional Pakar ke 1 Tahun 2018. Buku 2 ISSN (P): 2615 - 2584 ISSN (E): 2615 - 3343.

Hasibuan, Marcelia. 2012. Strategi Perencanaan dan Pengembangan Objek Wisata (Studi Kasus: Pantai Pengandaran Kabupaten Ciamis Jawa Barat). Jurnal. :Politeknik Negeri Bandung.

Hidayat,Muhammad. 2012. Strategi Perencanaan dan Pengembangan ISSN: 2302 - 6715 NATURALIS - Jurnal Penelitian Pengelolaan Sumberdaya Alam dan Lingkungan 115 Objek Wisata (Studi Kasus: Pantai Pengandaran Kabupaten Ciamis Jawa Barat). Jurnal. :Politeknik Negeri Bandung.

Menteri Pariwisata Republik Indonesia. Peraturan Menteri Pariwisata Republik Indonesia Nomor 14 Tahun 2016 Tentang Pedoman Destinasi Pariwisata Berkelanjutan. Indonesia, 2016.

Metodelogi Penelitian. Bab 3. Universitas Islam Indonesia. Tersedia di: http://etheses.uinmalang.ac.id/1960/7/10520021_Bab_3.pdf. Diakses Pada 21 Februari 2021 
Mutiara, Ikhlassia dkk. Potensi Pengembangan Pariwisata Pantai Sempaning Kota Bengkulu Dalam Perspektif Konservasi Lingkungan. Jurnal Penelitian Pengelolaan Sumber Daya Alam dan Lingkungan. Hal 109-115.

Nurhidayati dan Chafid Fandeli. 2012. Penerapan Prinsip Community Based Tourism (CBT (Community Based Tourism) Dalam Pengembangan Agrowisata Di Kota Batu, Jawa Timur. Jejaring Administrasi Publik. Th IV. Nomor 1, Januari-Juni 2012. Hal 36-46.

Oktavallyan dkk. 2020. Pendampingan Pembuatan Desain Kawasan Pariwisata Berbasis Komunitas (Community Based Tourism) pada Kelompok Sadar Wisata di Kawasan Danau Gedang Kabupaten Bengkulu Tengah. Jurnal Pengabdian Masyarakat. Volume 04, Number. 01, May, 2020, pp. $076-086$.

Profil Kabupaten Badung. File tersedia di:

(https://sippa.ciptakarya.pu.go.id/sippa_online/ws_file/dokumen/rpi2jm/DOCRPIJM_1504704 048Bab4-Profil_KabKota_bdg.pdf). Diakses Pada 20 Februari 2021

Rahma, Aulia.2020. Potensi Sumber Daya Alam dalam Mengembangkan Sektor Pariwisata di Indonesia. Jurnal Nasional Pariwisata. Vol. 12.

Sugi Rahayu, Utami Dewi, dan Kurnia Nur Fitriana. Pengembangan Community Based Tourism Sebagai Strategi Pemberdayaan Ekonomi Masyarakat Di Kabupaten Kulon Progo, Daerah Istimewa Yogyakarta. Jurnal Penelitian Humaniora, Vol. 21, No. 1, April 2016: 1-13.

Untari, Dewi dan Dewi Endah Fajariana. 2018. Strategi Pemasaran Melalui Media Sosial Instagram (Studi Deskriptif Pada Akun @Subur_Batik). Jurnal Sekretari dan Manajemen. Volume 2 No. 2 September 2018 P-ISSN 25500805 E-ISSN 2550-0791. Tersedia di: http://ejournal.bsi.ac.id/ejurnal/index.php/widyacipta. 